\title{
PRESERVATION OF ANTIOXIDANT DEFENSE SYSTEM BY MORIN IN BICALUTAMIDE-INDUCED RAT TESTICULAR TOXICITY
}

\author{
Olayinka, E.T., Ore, A., Olotu, O.O., Ogbuji, V.U., Adeyemo, O.A., Ola, O.S.
}

Biochemistry Division, Department of Chemical Sciences, Faculty of Natural Sciences, Ajayi Crowther University, Oyo, Nigeria.

Authors' email addresses: OET-et.olayinka@acu.edu.ng, Tel: +2340868525507; OA-a.ore@acu.edu.ng; OOOolaoluolot@yahoo.co.uk; OVU-ogbujiuvera@gmail.com; AOA-dewumyt@gmail.com; OOS-os.ola@acu.edu.ng.

*Corresponding author's email: et.olayinka@acu.edu.ng

(Received: $23^{\text {rd }}$ January, 2020; Accepted: $09^{\text {th }}$ September, 2020)

\section{ABSTRACT}

Bicalutamide (BCT) is a potent anti-androgen chemotherapeutic drug indicated for prostate cancer. However, BCT is known to cause oxidative stress and impairment of male reproductive function. Whereas Morin (MOR), a flavonoid has been found to be a potent antioxidant, with free radical scavenging capacity. This study investigated the protective effect of MOR on BCT-induced testicular toxicity in Wistar rats. Twenty-four male albino rats were randomized into four groups ( $\mathrm{n}=6 /$ group). Group I which served as control received distilled water. Group II, received $3 \mathrm{mg} / \mathrm{kg}$ body weight (bwt) BCT orally (per os); group III received $3 \mathrm{mg} / \mathrm{kg} / \mathrm{day}$ BCT p.o. plus $100 \mathrm{mg} / \mathrm{kg} / \mathrm{d}$ MOR p.o. and group IV received $100 \mathrm{mg} / \mathrm{kg} / \mathrm{d}$ MOR p.o. All treatments lasted for 14 days, thereafter, animals were sacrificed and epididymis and testis were collected for sperm and biochemical analyses. The result revealed that BCT treatment caused a significant increase in abnormal sperm morphology. Sperm production, sperm count, motility and viability were significantly reduced when compared with control $(\mathrm{p}<0.05)$. Similarly, testicular superoxide dismutase (SOD), catalase (CAT), glutathione peroxidase $(\mathrm{GPx})$, glutathione S-transferase (GST) and acid phosphatase (ACP) activities, as well as ascorbic acid and GSH levels were significantly reduced in the BCT- treated animals when compared to control $(\mathrm{p}<0.05)$. Conversely, testicular alkaline phosphatase (ALP), gamma glutamyl transferase (GGT) and lactate dehydrogenese (LDH) activities as well as malondialdehyde (MDA) levels of BCT-treated animals increased significantly relative to control $(\mathrm{p}<0.05)$. However, co-treatment with Morin ameliorated BCT-induced alterations in sperm parameters, ascorbic acid, GSH and MDA levels, as well as LDH, SOD, CAT, GST, GPX, ACP, ALP and GGT activities. Data obtained from this study suggest that Morin protected against altered sperm parameters and testicular oxidative stress caused by BCT.

Keywords: Bicalutamide, Anti-androgen, Testis, Oxidative stress, Morin, Antioxidant, Rat

\section{INTRODUCTION}

Bicalutamide N-[4-cyano-3-(trifluoromethyl) phenyl]-3-(4-fluorophenyl)sulfonyl-2-hydroxy-2methylpropanamide (Figure 1a) is a potent nonsteroidal anti-androgen chemotherapeutic drug. It is primarily indicated for prostate cancer treatment with proven efficacy at various stages of the disease and could also be used in the treatment of hirsutism (Lunglmayr, 1995). BCT is orally ingested, and it is metabolized by the action of
CYP 3A4 (Cockshott, 2004). Thereafter, it functions as an androgen receptor inhibitor thus competitively inhibiting the action of androgens of adrenal and testicular origin which foster the growth of prostatic tissue. BCT prevents the upregulation of androgen responsive genes by androgenic hormones (Furr et al., 1996) and further fosters the degradation of the androgen receptor. 
<smiles>CC(O)(CS(=O)(=O)c1ccc(F)cc1)C(=O)Nc1ccc(C#N)c(C(F)(F)F)c1</smiles>

(a)<smiles>O=c1c(O)c(-c2ccc(O)cc2O)oc2cc(O)cc(O)c12</smiles>

(b)

Figure 1: Structure of (a) Bicalutamide and (b) Morin

Despite its proven efficacy, BCT is associated with some toxic side effects. It has been reported to cause decrease in sperm count, depletion of germinal layer, and a decrease in testosterone level (Abdulrahman and Mustafa, 2019). BCT has been found to promote reactive oxygen species (ROS) generation in prostate cancer cells, with a potential to contribute to drug-induced oxidative damage and apoptosis (Hanane et al., 2012). Reported reproductive impairments from BCT are related to histological changes to the testicular germinal layer, decrease in sperm count, increasing the apoptotic index of germinal layer cells and decrease in testosterone level (Hanane et al., 2012; Abdulrahman and Mustafa, 2019).

Chemotherapy-induced toxicity is a common occurrence in patients undergoing cancer chemotherapy, especially when the treatment will span a long period (Toale et al., 2016). In most cases involving short term treatments, the toxic effects of chemotherapeutic agents such as oxidative damage, impairment of spermatogenesis, sperm maturation and sexual function may be reversible after the discontinuation of the drug. However long term treatments may have serious negative impact on sperm parameters as well as sperm DNA and may be potentially irreversible. In order to mitigate the side effects of these chemotherapeutics, antioxidants are used as adjuvant therapy (Ilghami et al., 2020). Consequently, organ functions may be preserved during drug use with minimal interference with the pharmacological properties of the chemotherapeutic drug. Therefore, compounds of plant origin especially those with antioxidant activities have a vital role to play in drug-induced toxicities including oxidative damage.

Morin (2',3,4',5,7-pentahydroxyflavone), figure $1 \mathrm{~b}$, is a naturally occurring bioflavonoid, with a strong ability to protect against oxidative stress and inflammation (Sinha et al., 2016). In addition, it possesses a number of other effects including the immunomodulation and anticancer activity (Caselli et al., 2016; Sinha et al., 2016). Our earlier studies showed that MOR protected against sperm alteration and testicular oxidative stress induced by procarbazine (an alkylating agent) in rat (Olayinka et al., 2019). Previous studies have shown that co-administration of anticancer drugs and antioxidants compounds protected against chemotherapy-induced toxicities and improve the overall therapeutic outcome (Singh et al., 2018). Therefore, this study was designed to investigate the protective effect of MOR against BCT induced testicular toxicity and oxidative stress in rats.

\section{MATERIALS AND METHODS}

\section{Chemicals and Reagents}

Bicalutamide (Casodex ${ }^{\circledR}$, AstraZeneca Pharmaceuticals LP, Wilmington); Glutathione (GSH), 1-chloro-2, 4-dinitrobenzene (CDNB), 5', 5'-dithio-bis-2-nitrobenzoic acid (DTNB), 
thiobarbituric acid (TBA), epinephrine and hydrogen peroxide were purchased from Sigma Chemical Company (London, UK). Acid phosphatase, alkaline phosphatase, Gamma glutamyl transpeptidase and lactate dehydrogenase kits were obtained from Randox Laboratories Ltd (Antrim UK). All other chemicals and reagent were of analytical grade.

\section{Experimental Animals}

Twenty four male albino rats $(148 \pm 10 \mathrm{~g})$ were used in this study. The rats were housed in wire-meshed cages and allowed to acclimatize for one week prior to the commencement of study. Rats were fed with commercial rat chow (Ladokun ${ }^{\circledR}$ Feeds, Nigeria Ltd., Ibadan, Nigeria) and water ad libitum. Handling of experimental animals conforms to international guidelines on the care and use of animals in research.

\section{Experimental Design}

Rats were randomized into four experimental groups ( $\mathrm{n}=6 /$ group). Group I animals served as control and received distilled water. On daily basis, animals in Group II; received $3 \mathrm{mg} / \mathrm{kg} /$ body weight (bwt) BCT orally (per os) 14 days, group III received $3 \mathrm{mg} / \mathrm{kg} / \mathrm{d}$ BCT p.o. plus $100 \mathrm{mg} / \mathrm{kg} / \mathrm{d}$ MOR p.o., and group IV received $100 \mathrm{mg} / \mathrm{kg} / \mathrm{d}$ MOR p.o. While $3 \mathrm{mg} / \mathrm{kg} / \mathrm{d}$ BCT p.o. represents the dosage for the treatment of a locally advanced prostate cancer, $100 \mathrm{mg} / \mathrm{kg} / \mathrm{d}$ MOR p.o. was selected on the basis of its effectiveness in earlier studies (Kolvenbag and Nash, 1999; Kuzu et al., 2019; Olayinka et al., 2019).

All treatments lasted for a period of 14 days. Rats were euthanized twenty four hours after the last administration. Epididymis and testis were collected for sperm analysis and preparation of homogenate respectively.

\section{Sperm Analysis}

Sperm was obtained by mincing the epididymis in normal saline and filtering through a nylon mesh. The spermatozoa were counted using the Neubauer hemacytometer adopting the method described by Pant and Srivastava (2003). Sperm motility was evaluated visually at $400 \mathrm{x}$ magnification within $2-4$ minute of their isolation from the cauda. Motility estimations were performed from the entire field in each sample.
The mean was used as the final motility score and data were expressed as percentages (Sönmez et al., 2007). A portion of the sperm suspension placed on a glass slide was smeared out with another slide, fixed in 95\% ethanol, and stained with 1\% eosin and $5 \%$ nigrosin for morphological and viability observation. At least 100 sperms from each rat were examined for abnormalities in different regions of spermatozoa according to the method described by Wyrobek et al. (1983).

\section{Preparation of Testes Homogenate}

Testis was rinsed in ice-cold $\mathrm{KCl}(1.15 \%)$, blotted, weighed and $0.5 \mathrm{~g}$ was homogenized in $2 \mathrm{ml}$ of 0.1 $\mathrm{M}$ phosphate buffer ( $\mathrm{pH}$ 7.4). The homogenates were centrifuged at $12,000 \mathrm{~g}$ for $10 \mathrm{~min}$ at $4{ }^{\circ} \mathrm{C}$. The supernatant obtained was stored at $-20^{\circ} \mathrm{C}$ until used for biochemical analysis.

\section{Biochemical Analysis}

Protein concentration in samples was determined by the biuret method (Gornall et al., 1949). Malondialdehyde (MDA), a product of lipid peroxidation was estimated in the homogenate by the method of Varshney and Kale (1990). Concentration of non-enzymic antioxidants, ascorbic acid (AscA) and reduced glutathione (GSH) were determined by the method of Jagota and Dani (1982) and Jollow et al. (1974) respectively. Superoxide dismutase (SOD) activity was determined according to the method described by Misra and Fridovich (1972). Catalase (CAT) activity was determined by the procedure described by Hadwan and Abed (2016). Glutathione peroxidase (GSH-Px) activity was determined according to Rotruck et al. (1973), and glutathione S-transferase (GST) activity was determined according to Habig et al. (1974). Testicular activities of acid phosphatase (ACP), alkaline phosphatase (ALP), lactate dehydrogenase $(\mathrm{LDH})$ and $\gamma$-glutamyl transferase $(\gamma-G T)$, were determined using Randox diagnostic kits, according to the manufacturer's protocol.

\section{Statistical Analysis.}

Results are expressed as mean \pm SD. Data obtained were subjected to one-way analysis of variance (ANOVA) and complemented with Duncan's multiple range test using Sigma Plot Statistical Software. A value of $\mathrm{P}<0.05$ was accepted as statistically significant. 


\section{RESULTS}

Effect of MOR on Sperm Quality in BCTinduced Rats

Table 1 shows the result of MOR protective effect on BCT-induced changes in sperm parameters. BCT was observed to cause a significant $(\mathrm{P}<0.05)$ decrease in percentage normal sperm cells, sperm cell motility, sperm cell viability and total number of sperm cells compared to the control rats. However, administration of MOR alongside BCT significantly ameliorated the alterations in sperm parameters caused by BCT.

Table 1: Effects of MOR on BCT-induced Alterations in Sperm Parameters

\begin{tabular}{cccccc}
\hline $\begin{array}{c}\text { Treatment } \\
\text { Groups }\end{array}$ & $\begin{array}{c}\text { Normal } \\
\text { Morphology (\%) }\end{array}$ & $\begin{array}{c}\text { Motility } \\
\mathbf{( \% )}\end{array}$ & $\begin{array}{c}\text { Viability } \\
\mathbf{( \% )}\end{array}$ & $\begin{array}{c}\text { Volume } \\
(/ \mathbf{m l})\end{array}$ & $\begin{array}{c}\text { Count } \\
\left(\times 10^{6} / \mathbf{m l}\right)\end{array}$ \\
\hline CONTROL & $89.6 \pm 0.15$ & $90 \pm 5.5$ & $97.5 \pm 1.2$ & $5.2 \pm 0.04$ & $132.5 \pm 3.4$ \\
BCT & $84.9 \pm 0.2^{*}$ & $72.9 \pm 4.9^{*}$ & $86.3 \pm 1.6^{*}$ & $5.2 \pm 0.05$ & $113.1 \pm 4.1^{*}$ \\
BCT+ MOR & $86.4 \pm 0.22^{* \#}$ & $79.2 \pm 3.8^{*, \#}$ & $91.7 \pm 4.1^{*, \#}$ & $5.2 \pm 0.05$ & $120.3 \pm 1.5^{*}, \#$ \\
MOR & $87.9 \pm 0.15^{*}$ & $85 \pm 4.5^{*}$ & $94.3 \pm 3.6^{*}$ & $5.2 \pm 0.05$ & $126.0 \pm 4.1^{*}$ \\
\hline
\end{tabular}

Values represent mean $\pm \mathrm{SD}(\mathrm{n}=6)$; *significantly different from the control; \# significant compared with $\mathrm{BCT}(\mathrm{P}<0.05)$; BCT-bicalutamide; MOR-Morin

\section{Effects of MOR on BCT Induced- Oxidative Stress}

Figure 2 shows the protective effect of MOR on BCT-induced oxidative stress and alteration in testicular antioxidant defense. Compared with the control group, BCT caused a significant increase in level of MDA a product of lipid peroxidation. Co-treatment with MOR, however, alleviated increase in testicular MDA levels. Testicular levels of the non-enzymatic antioxidants: AscA and
GSH decreased significantly in the BCT group when compared with the control (Figure $2 \mathrm{~b}$ and Figure 2c). A similar reduction was also observed in the activities of enzymatic antioxidants: SOD, CAT, GPx, and GST as shown in figures $2 \mathrm{~d}, 2 \mathrm{e}, 2 \mathrm{f}$ and $2 \mathrm{~g}$ respectively. However, administration of MOR alongside BCT significantly alleviated the decrease in testicular antioxidants caused by BCT in rats. 

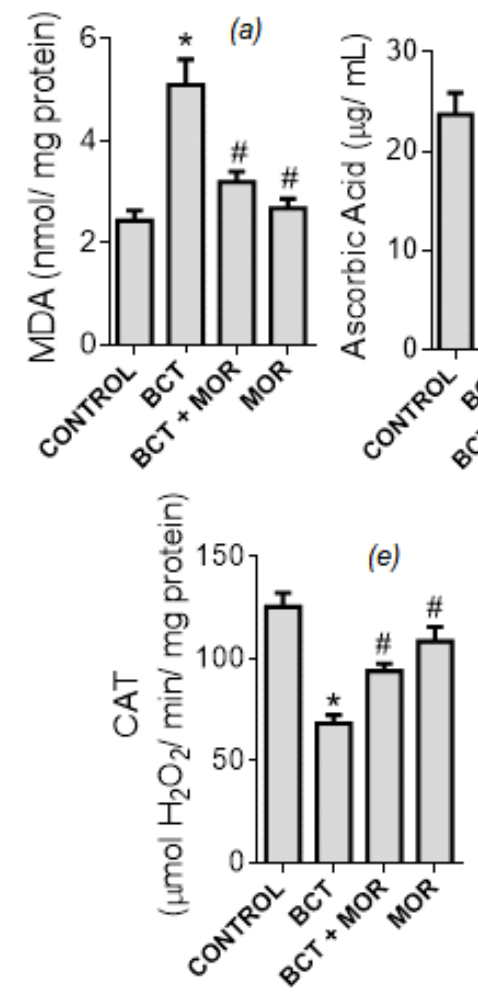

(b)
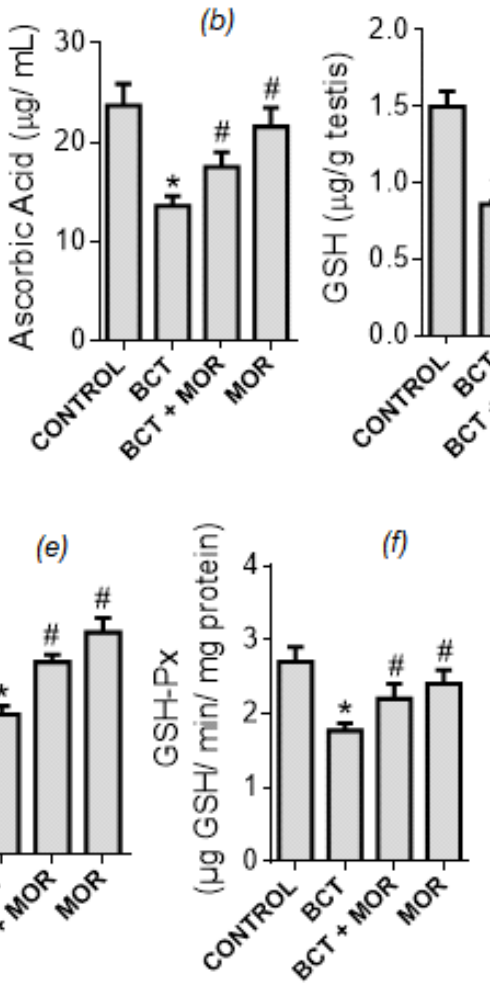

(c)

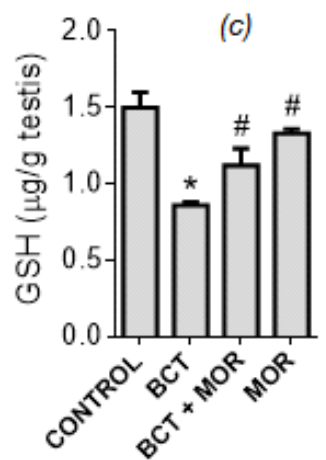

(d)

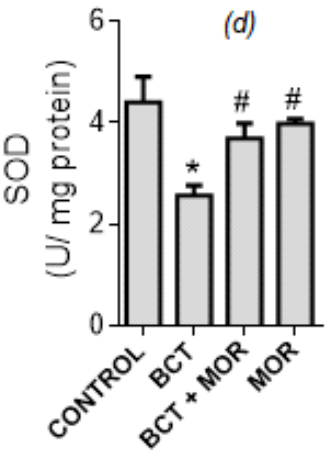

(g)

Figure 2: Protective effect of Morin on Bicalutamide-induced Changes in Testicular (a) MDA Content, (b) AscA Level, (c) GSH Level, (d) SOD Activity, (e) CAT Activity, (f) GSH-Px Activity and (g) GST Activity

Each bar represents the mean \pm SD of six replicates; * significantly different from the control; \# significant compared with BCT $(\mathrm{P}<0.05)$; BCT - bicalutamide; MOR - Morin.

Influence of MOR in Testicular Indices of BCT-induced rats

Figure 3 shows the effects of MOR on BCTinduced alterations in activities of some testicular function enzymes. BCT caused a significant decrease in testicular ACP (Figure 3a) activity when compared with the control. However, testicular activities of ALP (Figure 3b), LDH (Fig 3c) and $\gamma$-GT (Fig 3d) decreased significantly following BCT treatment. Administration of MOR along with BCT ameliorated the BCT induced alterations in testicular activities of ACP, ALP, LDH and ã-GT as shown in figures 3 a, b, c and d respectively.
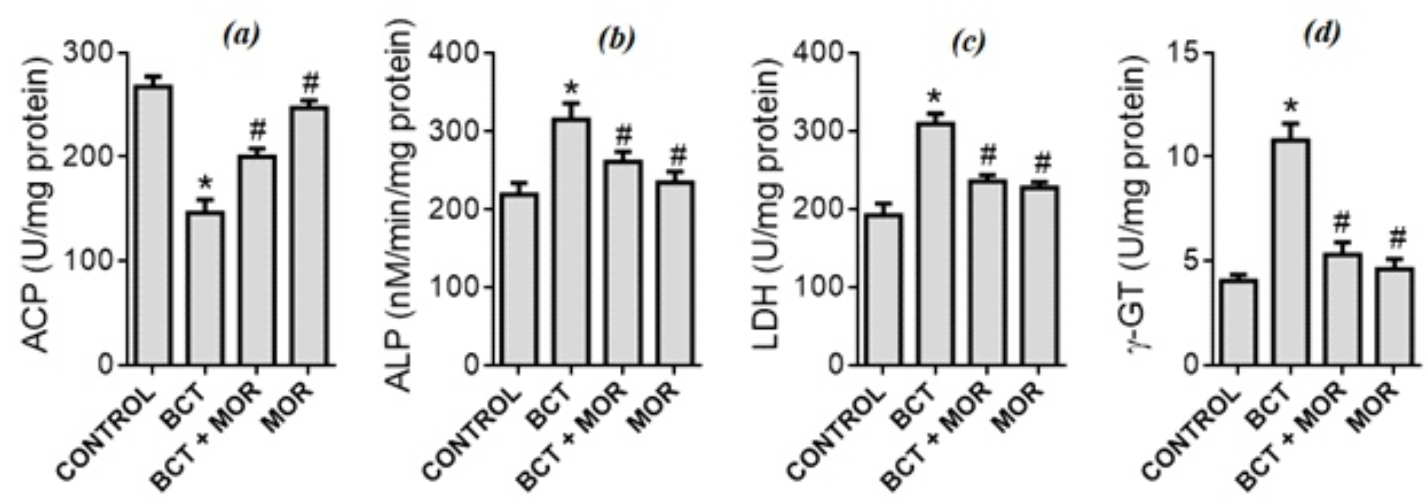

Figure 3: Protective Effect of Morin on Bicalutamide-induced Changes in the Testicular

Enzyme Activities of (a) ACP, (b) ALP, (c) LDH and (d) $\gamma$-GT

Each bar represents the mean \pm SD of six replicates; *significantly different from the control; \# significant compared with BCT $(\mathrm{P}<0.05)$; BCT - bicalutamide; MOR - Morin. 


\section{DISCUSSION}

Data obtained from this study show a significant alteration in sperm parameters in BCT treated rats. Sperm morphology, motility, and total count are important indicators of male reproductive function. Sperm morphology refers to characteristic appearance of the head, neck, and tail while motility is the ability of sperm cell to move (Prajapati and Solanki, 2011). The increase in abnormal sperm coupled with decrease in motility, viability and total sperm cell count is consistent with an earlier report on BCT (Adeniyi et al., 2009; Abdulrahman and Mustafa, 2019). A significant improvement was observed when MOR was administered along with BCT which is in agreement with previous reports on the protective effects of MOR on testicular function (Olayinka et al., 2019).

The testis contains a formidable antioxidant defence system comprising non-enzymic antioxidants and enzymic antioxidant enzymes. It was observed that BCT caused oxidative stress in rats as indicated by a significant increase in testicular MDA level and decrease in testicular antioxidant status. Significant decrease in AscA and GSH levels as well as activities of SOD, CAT, GPx, and GST was observed in BCT treated rats. AscA and GSH are noted to play vital roles as free radical scavengers in cells and for their protections against oxidation of biomolecules in tissues (Dabrowski and Ciereszko, 1996; Kojo, 2004). Testicular redox system had been documented to be maintained by the activities of SOD, CAT, GSH-Px, and GST (Aitken and Roman, 2008). SOD is involved in the dismutation of superoxide radical to $\mathrm{H}_{2} \mathrm{O}_{2}$ and $\mathrm{O}_{2}$, while CAT and GSH-Px catalyse the conversion of $\mathrm{H}_{2} \mathrm{O}_{2}$ into $\mathrm{H}_{2} \mathrm{O}$ and $\mathrm{O}_{2}$ (Asadi et al., 2017). GST on the other hand uses GSH as endogenous substrate in the detoxication of drugs and toxicants (Allocati et al., 2018). Oxidative stress has been shown to contribute to abnormal sperm formation and decrease in total sperm count and may have negative effects on sperm function as well as male fertility (Aprioku, 2013). The study shows that administration of MOR alongside BCT significantly ameliorated the BCT-induced lipid peroxidation and depletion of testicular antioxidant system. This is consistent with previous reports on the protective effects of MOR against oxidative stress caused by chemotherapeutic agents (Olayinka et al., 2019).

Data from this study also show that BCT administration significantly altered testicular activities of ACP, ALP, LDH and ã-GT in the treated rats. ACP is an enzyme of lysosomal origin present in germ cells and its activities increase with increase in testicular steroidogenesis (Chitra et al., 1999). The observed decrease in testicular ACP may reflect decreased testicular steroidogenesis in the BCT-treated rats. ALP is a ubiquitous enzyme that is associated with cell membrane and its activity is vital to spermatogenesis (Chaudhuri et al., 1991). LDH activity is associated with testicular energy metabolism and it is also a vital biomarker for spermatogenic cell function (Rato $e t$ al., 2012). ã-GT is a useful biomarker of sertoli cell function and is equally involved in the metabolism of extracellular GSH (Sherins and Hodgen, 1976). The observed decrease in $\gamma$-GT activity in the testes of BCT-treated animals probably elicits negative influence on the delivery of GSH to testicular cells. However, administration of MOR alongside BCT in this study significantly improved the BCT-induced alterations in the activities of these enzymes in rat testis.

\section{CONCLUSIONS}

The present study demonstrated that Morin possesses the capacity to protect against BCTinduced oxidative damage in rat testis. This observation suggests a possible use of Morin as a supplement during a prolonged period of chemotherapy with BCT related drugs.

\section{REFERENCES}

Abdulrahman, A.S. and Mustafa, I.A. 2019. Impact of bicalutamide, an anti-androgen on rat testis. ZANCO Journal of Pure and Applied Sciences (ZJPAS), 31(2): 89-100.

Adeniyi. A., Oremosu, A., Olabiyi, O., Akang, E., Noronha, C. and Okanlawon. A. 2009. The protective role of ascorbic acid administration on the Bicalutamideinduced reduction in semen quality in the Sprague - Dawley rat. The Internet Journal of Health, 12(1): 1-6.

Aitken, R.J. and Roman, S.D. 2008. Antioxidant systems and oxidative stress in the testes. Oxidative Medicine and Cellular Longevity, 1(1):15-24. 
Allocati, N., Masulli, M., Di Ilio, C. and Federici, L. 2018. Glutathione transferases: substrates, inhibitors and pro-drugs in cancer and neurodegenerative diseases. Oncogenesis, 7(1): 1-15.

Aprioku, J.S. 2013. Pharmacology of free radicals and the impact of reactive oxygen species on the testis. Journal of Reproduction and Infertility, 14: 158-172.

Asadi N, Bahmani M, Kheradmand A, RafieianKopaei M. 2017. The impact of oxidative stress on testicular function and the role of antioxidants in improving it: a review. Journal of Clinical and Diagnostic Research, 2017:11:1-5.

Caselli, A., Cirri, P., Santi, A., Paoli, P. 2016. Morin: A promising natural drug. Current MedicinalChemistry, 23(8): 774-791.

Chaudhuri, A., Biswas, N.M., Ghosh, D. and Ghosh, P.K. 1991. Changes in the testicular acid and alkaline phosphatase activities at different durations following prostatectomy: a correlative study with spermatogenesis. Acta Pbysiologica Hungarica, 78(1): 55-59.

Chitra K.C., Latchoumycandane, C., Mathur P.P. 1999. Chronic effect of endosulfan on the testicular functions of rat. Asian Journal of Andrology, 1:203-206.

Cockshott, I. D. 2004. Bicalutamide: Clinical pharmacokinetics and metabolism. Clinical Pharmacokinetics, 43(13): 855-878.

Dabrowski, K. and Ciereszko, A. 1996. Ascorbic acid protects against male infertility in a teleost fish. Experentia, 52: 97-100.

Furr, B.J.A., Blackledge, G.R.P. and Cockshott, I.D. 1996. Casodex: preclinical and clinical studies. In: Pasqualini, J.R. and Katzenellenbogen, B.S. (eds.). Hormone dependent cancer. New York (NY): Marcel DekkerInc, pp.397-424.

Gornall, A.G., Bardawill, C.J. and David, M.M. 1949. Determination of serum proteins by means of the biuret reaction. Journal of Biological Chemistry, 177: 751-766.

Habig, W.H., Pabst, M.J. and Jakoby, W.B. 1974. Glutathione S-transferases. The first enzymatic step in mercapturic acid formation. Journal of Biological Chemistry, 249(22): 7130-7139.

Hadwan, M.H. and Abed, H.N. 2016. Data supporting the spectrophotometric method for the estimation of catalase activity. Data in Brief, 6: 194-199.

Hanane, A., Claire L., Caroline, A. and Fabrice, M. 2012. Anticancer Drug Metabolism: Chemotherapy Resistance and New Therapeutic Approaches. Topics on Drug Metabolism, Paxton, J. (Ed.), InTech, UK.

Ilghami, R., Barzegari, A., Mashayekhi, M.R., Letourneur, D., Crepin, M. and PavonDjavid, G. 2020. The conundrum of dietary antioxidants in cancer chemotherapy. Nutrition Reviews, 78(1): 6576.

Jagota, S.K. and Dani, H.M. 1982. A new colorimetric technique for the estimation of vitamin $\mathrm{C}$ using Folin phenol reagent. Analytical Biochemistry, 127: 178-182.

Jollow, D.J., Mitchell, J.R., Zampaghone, N. and Gillete, J. R. 1974. Bromobenzene induced liver necrosis, protective role of glutathione and evidence for 3,4 bromobenzene oxide as the hepatotoxic metabolite. Pharmacology, 11:151-169.

Kojo, S. 2004. Vitamin C: basic metabolism and its function as an index of oxidative stress. Current Medicinal Chemistry, 11:1041-1064.

Kolvenbag, G.J. and Nash, A. 1999. Bicalutamide dosages used in the treatment of prostate cancer. Prostate, 39(1):47-53.

Kuzu, M., Yýldýrým, S., Kandemir, F.M., Küçükler, S., Çaðlayan, C., Türk, E. and Dörtbudak, M.B. 2019. Protective effect of Morin on doxorubicin-induced hepatorenal toxicity in rats. ChemicoBiological Interaction, 308: 89-100.

Lunglmayr, G. 1995. Efficacy and tolerability of Casodex in patients with advanced prostate cancer. International Casodex Study Group. Anticancer Drugs, 6: 508-513.

Misra, H.P. and Fridovich, I. 1972. The role of superoxide anion in the autooxidation of epinephrine and a simple assay for superoxide dismutase. Journal of Biological Chemistry, 247: 3170-3175.

Olayinka, E.T., Ore, A., Adeyemo, O.A., Ola, O.S. 2019. The role of flavonoid antioxidant, Morin in improving procarbazineinduced oxidative stress on testicular function in rat. Porto Biomedical Journal, 4:1(e28). 
Pant, N. and Srivastava, S.P. 2003. Testicular and spermatotoxic effect of quinaphos in rats. Journal of Applied Toxicology, 23: 271-274.

Prajapati, P.M. and Solanki, A.S. 2011. Sperm abnormality and its treatment. International Research Journal of Pharmacy, 2: 46-49.

Rato, L., Alves, M.G., Socorro, S., Duarte, A.I., Cavaco, J.E. and Oliveira, P.F. 2012. Metabolic regulation is important for spermatogenesis. Nature Reviews Urology, 9: 330-338.

Rotruck, J.T. Pope, A.L., Ganther, H.E., Swanson, A.B., Hafeman, D.G. and Hoekstra, W.G. 1973. Selenium: biochemical role as a component of glutathione peroxidase. Science, 179: 588-590.

Sherins, R.J. and Hodgen, G.D. 1976. Testicular gamma glutamyl-transpeptidase: an index of Sertoli cell function in man. Journal of Reproduction and Fertility, 48: 191-193.

Singh, K., Bhori, M., Kasu, Y.A., Bhat, G. and Marar, T. 2018. Antioxidants as precision weapons in war against cancer chemotherapy induced toxicity Exploring the armoury of obscurity. Saudi Pharmaceutical Journal, 26(2): 177-190.

Sinha, K., Ghosh, J. and Sil, P.C. 2016. Morin and Its Role in Chronic Diseases. Gupta, S.C., Prasad, S. and Aggarwal, B. (eds.), Anti- inflammatory Nutraceuticals and Chronic Diseases, Springer International Publishing, Switzerland, pp. 453-471.

Sönmez, M., Yüce, A. and Türk, G. 2007. The protective effects of melatonin and vitamin $E$ on antioxidant enzyme activities and epididymal sperm characteristics of homocysteine treated male rats. Reproductive Toxicology, 23: 226-231.

Toale, K. M., Johnson, T. N. and Ma, M. Q. 2016. Chemotherapy-Induced Toxicities. In K.H. Todd, C.R. Thomas, Jr. (eds.), Oncologic Emergency Medicine. Springer International Publishing Switzerland, 381-406.

Varshney, R. and Kale, R.K. 1990. Effect of calmodulin antagonist on radiation induced lipid peroxidation in microsomes. International Journal of Radical Biology, 58: 733-743.

Wyrobek, A.J., Gordon, L.A., Burkhart, J.G., Francis, M.W., Kapp, R.W., Letz, G., Malling, H.V., Topham, J.C. and Whorton, M.D. 1983. An evaluation of the mouse sperm morphology test and other sperm tests in non-human mammals. A report of the United States Environmental Protection Agency Gene-Tox Programme. Mutation Research, 115:1-72. 